University of Nebraska - Lincoln

DigitalCommons@University of Nebraska - Lincoln

Agronomy \& Horticulture -- Faculty Publications

Agronomy and Horticulture Department

November 1999

\title{
Yield Potential Trends of Tropical Rice since the Release of IR8 and the Challenge of Increasing Rice Yield Potential
}

\author{
S. Peng \\ International Rice Research Institute (IRRI), Makati City, Philippines \\ Kenneth G. Cassman \\ University of Nebraska-Lincoln, kcassman1@unl.edu \\ S. S. Virmani \\ Genetics, and Biochemistry Division, IRRI \\ J. Sheehy \\ International Rice Research Institute (IRRI), Makati City, Philippines \\ G. S. Khush \\ Genetics, and Biochemistry Division, IRRI
}

Follow this and additional works at: https://digitalcommons.unl.edu/agronomyfacpub

Part of the Plant Sciences Commons

Peng, S.; Cassman, Kenneth G.; Virmani, S. S.; Sheehy, J.; and Khush, G. S., "Yield Potential Trends of Tropical Rice since the Release of IR8 and the Challenge of Increasing Rice Yield Potential" (1999). Agronomy \& Horticulture -- Faculty Publications. 97.

https://digitalcommons.unl.edu/agronomyfacpub/97

This Article is brought to you for free and open access by the Agronomy and Horticulture Department at DigitalCommons@University of Nebraska - Lincoln. It has been accepted for inclusion in Agronomy \& Horticulture -Faculty Publications by an authorized administrator of DigitalCommons@University of Nebraska - Lincoln. 


\title{
Yield Potential Trends of Tropical Rice since the Release of IR8 and the Challenge of Increasing Rice Yield Potential
}

\author{
S. Peng,* K. G. Cassman, S. S. Virmani, J. Sheehy, and G. S. Khush
}

\begin{abstract}
Since the release of IR8 in 1966, 42 additional indica rice (Oryza sativa L.) cultivars developed by the International Rice Research Institute (IRRI) for the irrigated and favorable rainfed lowlands have been released in the Philippines. The maximum yield of IR8 has been reduced by about $2 \mathrm{Mg} \mathrm{ha}^{-1}$ during the past $30 \mathrm{yr}$. Empirical breeding for population improvement within the indica germplasm has resulted in the maintenance of rice yield potential in the tropics of about 10 $\mathrm{Mg} \mathrm{ha}^{-1}$. To break the yield barrier, several approaches are being explored. These include development of a new plant type (NPT) with low tillering capacity and large panicles from tropical japonica germplasm and exploitation of heterosis through intervarietal and intersubspecific hybrids. Hybrid rice between indicas increased yield potential by about $9 \%$ under the tropical conditions. The higher yield potential of indica/indica hybrids compared with indica inbred cultivars was attributed to the greater biomass production rather than harvest index. New plant type breeding has not yet improved yield potential due to poor grain filling and low biomass production. Factors that cause poor grain filling and low biomass production of the NPT lines have been identified. Selecting parents with good grain filling traits, introduction of indica genes into NPT's tropical japonica background, and a refinement of the original NPT design are expected to improve the performance of the NPT lines. Further enhancement in yield potential may be possible from use of intersubspecific heterosis between indica and NPT lines.
\end{abstract}

G LOBAL RICE PRODUCTION must reach $800 \mathrm{Tg}$ of paddy rice to meet projected demand in 2025, which is $266 \mathrm{Tg}$ more than rice production in 1995 (Table 1). This additional rice must come mainly from irrigated land in Asia because improving rice yields in most rainfed regions is constrained by drought, flooding, and poor soil quality (Cassman, 1999). Moreover, the scope for expansion of irrigated rice area is limited. In fact, cultivated rice area is decreasing in many Asian countries as a result of urbanization and industrialization. Therefore, the average yield of Asia's irrigated rice land must increase from 5.0 to $8.5 \mathrm{Mg} \mathrm{ha}^{-1}$ in the 30 -yr period from 1995 to 2025 . A mean yield of $8.5 \mathrm{Mg} \mathrm{ha}^{-1}$ is very close to the estimated climate-adjusted yield potential of present rice cultivars in the major rice-growing areas (Matthews et al., 1995). Rice cultivars with higher yield potential must be developed to maintain an exploitable gap between yield potential and average farm yields.

S. Peng and J. Sheehy, Agronomy, Plant Physiology and Agroecology Division, International Rice Research Institute (IRRI), P.O. Box 3127, 1271 Makati City, Philippines; K.G. Cassman, Dep. of Agronomy, Univ. of Nebraska, Lincoln, NE 68583; S.S. Virmani and G.S. Khush, Plant Breeding, Genetics, and Biochemistry Division, IRRI. Contribution of IRRI. Received 28 Dec. 1998. *Corresponding author (s.peng @cgiar.org).

Published in Crop Sci. 39:1552-1559 (1999).
In 1966, IRRI released IR8, the first high-yielding modern rice cultivar for the irrigated tropical lowlands. Since then, the primary emphasis of rice improvement has been directed towards incorporation of disease and insect resistance, shortening of growth duration, and improving grain quality (Khush, 1990). As a result, 42 indica inbred cultivars have been released for the irrigated and favorable rainfed lowland rice systems in the Philippines. In the late 1960s and early 1970s, yield of 9 to $10 \mathrm{Mg} \mathrm{ha}^{-1}$ was often reported for IR8 and other early IRRI cultivars under favorable irrigated conditions in the Philippines (De Datta et al., 1968; Chandler, 1969; Yoshida and Parao, 1972). The yield potential of current high-yielding inbred rice cultivars grown with irrigation in the tropical lowlands is $10 \mathrm{Mg} \mathrm{ha}^{-1}$. Therefore, rice yield potential has remained almost constant in the tropical environments. The theoretical potential yield has been estimated at $15.9 \mathrm{Mg} \mathrm{ha}^{-1}$ in these environments based on the total amount of incident solar radiation during the growing season (Yoshida, 1981). On the basis of this estimate, there appears to be a large gap between the yield potential of the best available rice cultivars and the maximum theoretical yield. At issue is whether this gap can be narrowed by genetic crop improvement.

Despite the apparent yield barrier, the quest for higher rice yield potential continued. Ku et al. (1999) explored the possibility of converting rice's $\mathrm{C}_{3}$ photosynthetic pathway into the $\mathrm{C}_{4}$ pathway by introducing the maize (Zea mays L.) phosphenolpyruvate carboxylase (PEPC) gene into rice. Zhang et al. (1996) introduced a gene from Escherichia coli encoding for ADP-glucose pyrophosphorylase (AGP) enzyme into rice with the goal of increasing starch biosynthesis during seed development. There is preliminary evidence that quantitative trait loci (QTL) alleles from a wild rice Oryza rufipogon Griffith when introduced to cultivated rice, may increase the yield potential by as much as $20 \%$ (Xiao et al., 1998). Setter et al. (1995) proposed to reduce panicle height in the canopy to increase canopy light interception, canopy photosynthesis and grain yield. In the past $10 \mathrm{yr}$, IRRI scientists initiated two new approaches to increase yield potential: (i) the development of a new plant type (NPT) from tropical japonica germplasm, and (ii) development of indica hybrid rice for the tropical environments. The purpose of this paper is to evaluate the yield potential trends of indica inbred cultivars since the release of IR8, and to report recent progress and challenges related to the yield potential of the NPT and hybrid rice.

Abbreviations: DAT, days after transplanting; DS, dry season; IRRI, International Rice Research Institute; LAI, leaf area index; NPT, new plant type; PhilRice, Philippine Rice Research Institute; WS, wet season. 


\section{Yield Potential Trends of Cultivars Developed by Empirical Breeding}

Empirical breeding consists of hybridization between the best adapted inbred parents and selection of progeny on the basis of yield per se. While other factors are also considered in the selection of new rice cultivars, such as disease and insect resistance and grain quality, each new cultivar must have yield equal or better than the previous releases. This approach has been the basis of indica cultivar development at IRRI. To date, 44 indica inbred cultivars from IRRI, including IR5 and IR8, have been released in the Philippines for the irrigated and favorable rainfed lowland rice systems (Table 2). These cultivars were named in an "IR" series until 1988, after which they have been designated as Philippine Seed Board Rice (PSBRc) cultivars. These cultivars and their derivatives have been widely grown in South and Southeast Asia and account for more than $80 \%$ of total rice production in this region (Khush, 1990).

In the late 1960s and early 1970s, yield of 9 to $10 \mathrm{Mg}$ $\mathrm{ha}^{-1}$ was often reported for IR8 and other early IRRI cultivars under favorable irrigated conditions in the Philippines (De Datta et al., 1968; Chandler, 1969; Yoshida and Parao, 1972). Today, the maximum yield obtained with the newly released cultivars under the best crop management practices is also in the 9 to $10 \mathrm{Mg}$ $\mathrm{ha}^{-1}$ range, and these yield levels are often achieved in agronomic trials conducted at the experimental station farms (Kropff et al., 1993; Peng et al., 1996). This suggests that yield potential of indica inbred cultivars has not changed during the past $30 \mathrm{yr}$. The yield plateau is also evident in the yield records from several long-term experiments in which the most recent elite rice genotypes have been continually substituted for older cultivars since the experiments were initiated in the 1960 s (Flinn et al., 1982; Cassman et al., 1995).

Another way to compare the yield potential of a historical time series of cultivars is to grow them simultaneously under the same conditions. Peng et al. (2000) selected 11 indica inbred cultivars and lines developed by IRRI and one cultivar developed by the Bureau of Plant Industry, Department of Agriculture, Philippines. The older cultivars were chosen because of the large area planted to each during different periods of the past $30 \mathrm{yr}$. The more recent cultivars and advanced lines were selected because of their superior performance in yield trials at IRRI and in the Philippine national
Table 1. Yield increase in Asian irrigated rice land to meet the population demand in 2025 .

\begin{tabular}{|c|c|c|c|c|}
\hline \multirow[b]{2}{*}{ Year } & \multirow{2}{*}{$\begin{array}{l}\text { World rice } \\
\text { production }\end{array}$} & \multicolumn{3}{|c|}{ Asian irrigated rice } \\
\hline & & Production & Area & Yield \\
\hline & 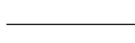 & 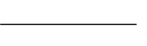 & Mg ha & $\mathrm{Mg} \mathrm{ha}^{-1}$ \\
\hline 1995 & 534 & 375 & 75 & 5.0 \\
\hline 2025 & 800 & 641 & 75 & 8.5 \\
\hline Difference & 266 & 266 & $\mathbf{0}$ & 3.5 \\
\hline
\end{tabular}

Source: FAO, FAOSTAT, 1995.

cooperative tests. These cultivars and lines were grown in two identical field experiments conducted in the 1996 dry season (DS): one at IRRI research farm in Los Baños and the other at the research farm of the Philippine Rice Research Institute (PhilRice) in Maligaya. Key growth parameters, yield, and yield components were measured. Regression of yield versus year of release indicated an annual gain in rice yield of $75 \mathrm{~kg}$ $\mathrm{ha}^{-1}$, equivalent to about $1 \%$ increase in yield per year based on the yield of IR8 (Fig. 1). The highest yields obtained with the most recently released cultivars was 9 to $10 \mathrm{Mg} \mathrm{ha}^{-1}$, which is equivalent to the yields obtained with IR8 and other IRRI cultivars in field studies conducted in the late 1960s and early 1970s at these same sites.

To confirm the results of Fig. 1, Peng et al. (unpublished) planted IR8 and IR72 under four levels of $\mathrm{N}$ in the 1998 DS. The maximum yield produced by IR8 was $7.2 \mathrm{Mg} \mathrm{ha}^{-1}$ at the $\mathrm{N}$ rate of $200 \mathrm{~kg} \mathrm{ha}^{-1}$. In contrast, IR8 produced $9.6 \mathrm{Mg} \mathrm{ha}^{-1}$ in the late 1960 s at the $\mathrm{N}$ rate of $120 \mathrm{~kg} \mathrm{ha}^{-1}$ at the same site (Fig. 2). The difference in yield of IR8 then and now appears to be the result of a reduction in grain filling percentage when IR 8 is grown in today's environment (Fig. 3). Therefore, the annual increase in yield estimated in the 1996 field study (Fig. 2) might not represent genetic gain in yield potential.

Because the older cultivars have longer growth duration than the more recent cultivars and the yield potential has not changed, there has been an increase in productivity per day. Although the empirical breeding of indica inbred cultivars in the past three decades has not improved rice yield potential, there have been important contributions to disease and insect resistance and yield stability. If IR8 had still been planted in the major rice growing areas of South and Southeast Asia, rice production in these areas would be reduced by as much as $20 \%$ because of the reduction in grain yield of IR8.

Table 2. The 44 indica inbred cultivars developed by the International Rice Research Institute (IRRI) for the irrigated and favorable rainfed lowland rice systems.

\begin{tabular}{lccccc}
\hline Cultivar & $\begin{array}{c}\text { Year } \\
\text { released }\end{array}$ & Cultivar & $\begin{array}{c}\text { Year } \\
\text { released }\end{array}$ & Cultivar & $\begin{array}{c}\text { Year } \\
\text { released }\end{array}$ \\
\hline IR5 & 1967 & IR36 & 1976 & IR54 & Iear \\
released
\end{tabular}




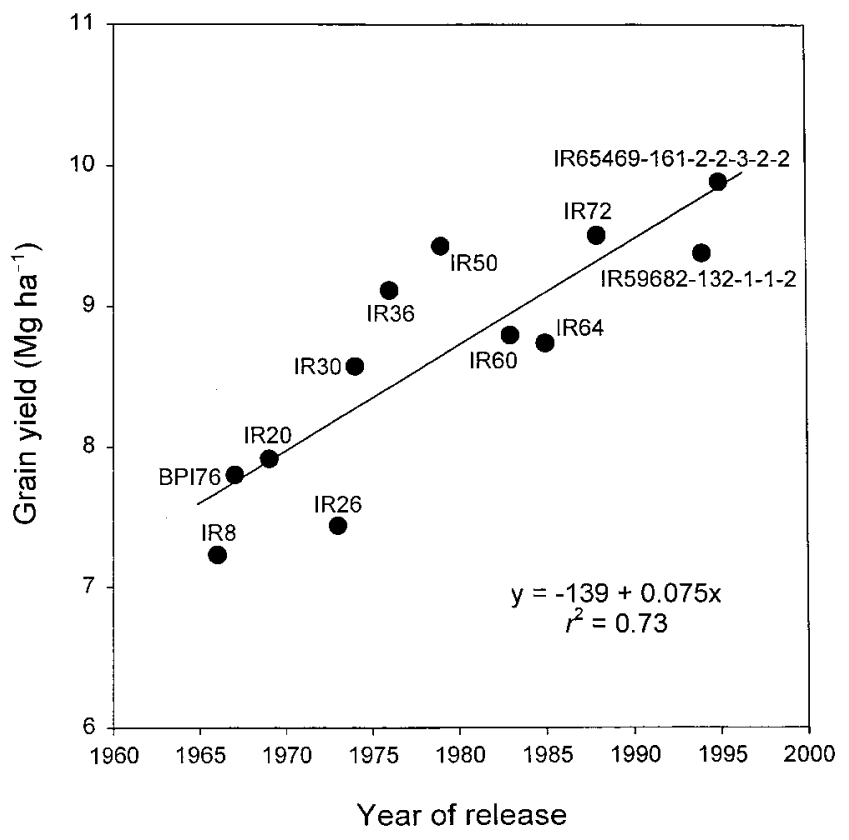

Fig. 1. Yield trend of cultivars and lines developed since 1966. BPI76 was developed by the Bureau of Plant Industry (BPI), Department of Agriculture, Philippines. Two new lines (IR59682-132-1-1-2 and IR65469-161-2-2-3-2-2) were developed in 1994 and 1995, respectively. The twelve cultivars and lines were grown at International Rice Research Institute (IRRI) farm and the Philippine Rice Research (PhilRice) farm in 1996 dry season under optimum crop management. Each data point is a mean of the two locations. Modified from the work of Peng et al. (2000).

\section{Status of New Plant Type Breeding}

Donald (1968) proposed the ideotype approach to plant breeding. In this approach, a plant type is defined which is theoretically more efficient than existing cultivars on the basis of knowledge of physiology and morphology. Breeders then begin to select directly for the

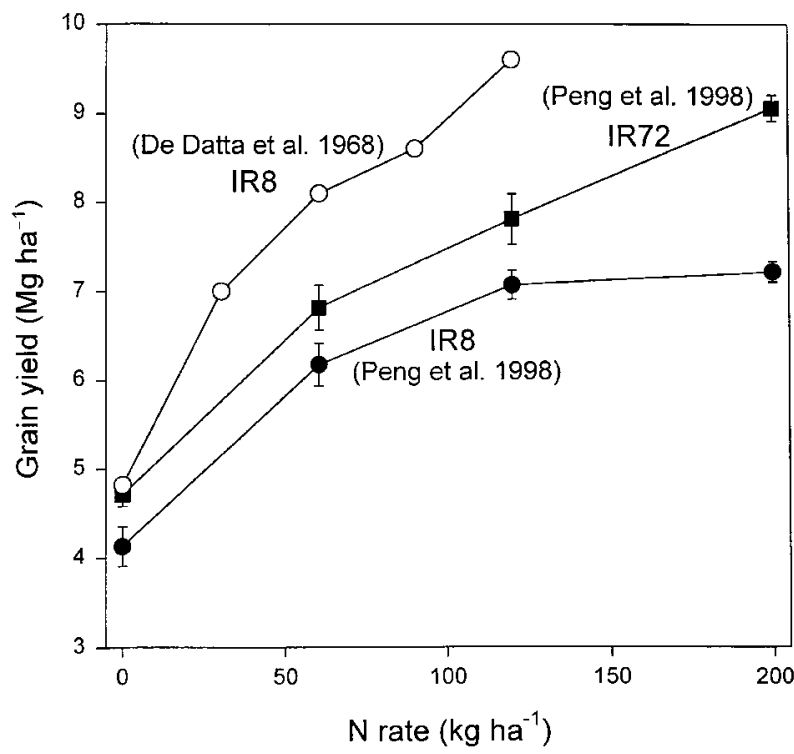

Fig. 2. Grain yield of IR8 and IR72 grown in the dry season of 1998 at IRRI farm in comparison with the grain yield IR8 grown in the late 1960s (De Datta et al., 1968) under various levels of fertilizer-N supply.

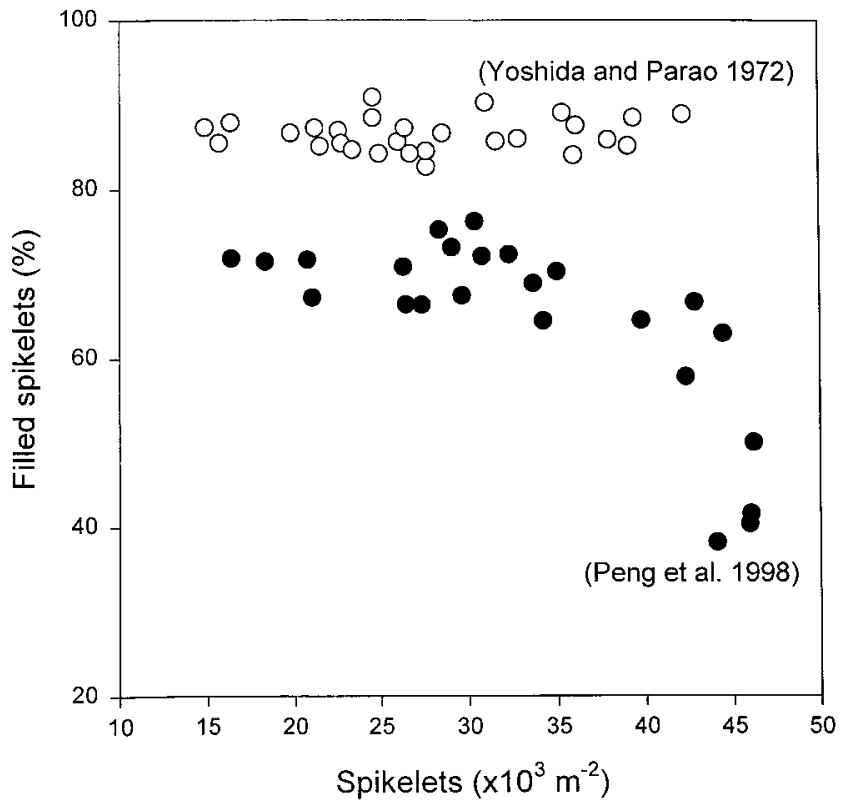

Fig. 3. Filled spikelet percentage of IR8 grown in the dry seasons of 1996 and 1998 at IRRI farm in comparison with the filled spikelet percentage of IR8 grown in the early 1970s (Yoshida and Parao, 1972).

ideotype, rather than for yield. Many ideotype traits such as plant height, tiller and panicle number, leaf orientation and color, and grain weight have been selection targets in most cereal breeding programs (Rasmusson, 1991).

In the late 1980s, it was postulated that the stagnant yield potential of semidwarf indica inbred rice cultivars might be the result of the plant type common to all of this germplasm. The "IR" cultivars produce a large number of unproductive tillers and have excessive leaf area which may cause mutual shading and a reduction in canopy photosynthesis and sink size, especially when grown under direct-seeded conditions (Dingkuhn et al., 1991). Most of these cultivars have high tillering capacity and small panicles. A large number of unproductive tillers, limited sink size, and lodging susceptibility were identified as the major constraints to increased yield potential in these cultivars. Simulation models predicted that a $25 \%$ increase in yield potential was possible by modification of the following traits of the current plant type (Dingkuhn et al., 1991): (i) enhanced leaf growth combined with reduced tillering during early vegetative growth, (ii) reduced leaf growth and greater foliar $\mathrm{N}$ concentration during late vegetative and reproductive growth, (iii) a steeper slope of the vertical $\mathrm{N}$ concentration gradient in the leaf canopy with a greater proportion of total leaf $\mathrm{N}$ in the upper leaves, (iv) increased carbohydrate storage capacity in stems, and (v) a greater reproductive sink capacity and an extended grain-filling period.

\section{History of Breeding for New Plant Type}

To break the yield potential barrier, IRRI scientists proposed modifications to the present high-yielding plant type. Although several crop physiologists pro- 
posed the framework of the new rice ideotype (Vergara, 1988; Janoria, 1989; Dingkuhn et al., 1991; Khush 1990), each of these proposed ideotypes has a number of features in common. These traits included low tillering capacity (three to four tillers when direct seeded); few unproductive tillers; 200 to 250 grains per panicle; a plant height of 90 to $100 \mathrm{~cm}$; thick and sturdy stems; leaves that were thick, dark green, and erect; a vigorous root system; 100 to $130 \mathrm{~d}$ growth duration; and increased harvest index.

This new ideotype became known as the "NPT" highlighted in IRRI's strategic plan (IRRI, 1989), and the breeding effort to develop this germplasm became a major research project. Breeding work began in 1989 when about 2000 entries from the IRRI germplasm bank were grown during the dry and wet seasons (WS) to identify donors for the desired traits (Khush, 1995). Donors for low tillering trait, large panicles, thick stems, vigorous root system, and short stature were identified in the "bulu" or javanica germplasm mainly from Indonesia. This germplasm is now referred to as the tropical japonica (Khush, 1995). Hybridization was initiated in the $1990 \mathrm{DS}$. The $\mathrm{F}_{1}$ progenies were grown in the 1990 $\mathrm{WS}, \mathrm{F}_{2}$ progenies in the $1991 \mathrm{DS}$, and the first pedigree nursery in the 1991 WS. Since then, more than 2000 crosses were made, 100000 pedigree lines were produced, and breeding lines with the desired morphological ideotype traits were selected. At present, about 500 NPT lines have been evaluated in observational yield trials.

\section{Initial Evaluation of New Plant Type Lines}

The tropical japonicas were developed into NPT lines in less than 5 yr. They were grown in a replicated observational trial for the first time in the 1993 WS and the characteristics of the NPT were compared with conventional inbred indica cultivars (Peng et al., 1994). Their morphophysiological traits and yield potential have been evaluated more rigorously since then in a number of locations and with various crop management practices (Khush and Peng, 1996). Optimum nitrogen management is most important for the full expression of yield potential in rice cultivars. The NPT lines and check cultivars were grown under various rates and timings of $\mathrm{N}$ applications to eliminate possible nitrogen deficiency at any growth stage (Khush and Peng, 1996). As intended, the NPT lines have large panicles, few unproductive tillers, and lodging resistance. However, grain yield was disappointing because of low biomass production and poor grain filling (Table 3 ). Reduced tillering capacity may contribute to low biomass production because the crop growth rate during vegetative stage of NPT lines is less than the indica cultivars. Less biomass production is also associated with poor grain filling, but the cause-and-effect relationship has not been established. The poor grain filling of NPT lines is probably due to lack of apical dominance within a panicle (Yamagishi et al., 1996), compact arrangement of spikelets on the panicle (Khush and Peng, 1996), a limited number of large vascular bundles for assimilate
Table 3. Comparison between a new plant type line (NPT, IR65598-112-2) and an indica cultivar (IR72) in grain yield, biomass production and grain filling percentage at different locations. Each value is a mean of four replications (mean \pm standard error of the mean).

\begin{tabular}{|c|c|c|c|c|c|c|}
\hline \multirow[b]{2}{*}{ Location } & \multicolumn{2}{|c|}{ Grain yield } & \multicolumn{2}{|c|}{ Biomass } & \multicolumn{2}{|c|}{ Grain filling } \\
\hline & NPT & IR72 & NPT & IR72 & NPT & IR72 \\
\hline
\end{tabular}

IRRI $\dagger \quad 8.4 \pm 0.3 \quad 8.9 \pm 0.2 \quad 15.5 \pm 0.5 \quad 16.7 \pm 0.6 \quad 52 \pm 3 \quad 79 \pm 1$

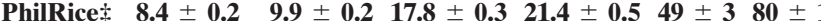
Yunnan§ $\quad 9.8 \pm 0.2 \quad 12.7 \pm 0.3 \quad 19.7 \pm 0.4 \quad 24.0 \pm 0.7 \quad 66 \pm 2 \quad 78 \pm 1$ $\begin{array}{llllllllll}\text { JapanIl } & 4.6 \pm 0.2 & 6.6 \pm 0.3 & 16.1 \pm 0.4 & 17.3 \pm 0.7 & 47 \pm & 1 & 67 \pm 3\end{array}$

$\dagger$ International Rice Research Institute Farm, 1994 dry season.

\$ Philippine Rice Research Institute Farm, 1995 dry season.

$\S$ Taoyuan Township, Yunnan Province, P.R. China, 1995.

II Yawara, Japan, 1994 (data from Dr. S. Akita, University of Tokyo).

transport (S. Akita, 1997, personal communication), and source limitation due to early leaf senescence (Ladha et al., 1998).

\section{Further Improvement of New Plant Type Lines}

The improvement of the NPT germplasm focuses on increasing grain filling percentage and greater biomass production. Improved disease and insect resistance is needed as well. In a recent field study, the grain filling of some parents of NPT lines was measured. A wide range in the percentages of filled and half-filled spikelets was found among the parents, and this variation was not correlated with spikelet number per panicle (Table 4). Perhaps more importantly, there was an indication that the grain filling percentage of the NPT lines was related to that of their parents (data not shown). Because a grain filling limitation was not thought to be a constraint when the initial NPT crosses were made, it was not considered in selecting parents. In subsequent crosses, only parents with good grain filling characteristics and large panicles were selected. As a result, some NPT lines produced higher yields than the IR72 check in the observational trials in the 1998 DS and 1998 WS (Table 5).

The introduction of traits from indica cultivars into NPT lines has also been initiated to broaden the genetic background of the NPT germplasm and to refine the

Table 4. Grain filling percentage and spikelet number per panicle of tropical japonica rice used as parents for developing new plant type, IRRI farm, 1996 wet season.

\begin{tabular}{lcccc}
\hline Genotype & $\begin{array}{c}\text { Filled } \\
\text { spikelets }\end{array}$ & $\begin{array}{c}\text { Half-filled } \\
\text { spikelets }\end{array}$ & $\begin{array}{c}\text { Empty } \\
\text { spikelets }\end{array}$ & $\begin{array}{c}\text { Spikelets } \\
\text { per panicle }\end{array}$ \\
\cline { 2 - 4 } & \multicolumn{4}{c}{$\%$} \\
Bali Ontjer & $\mathbf{8 3 . 8} \pm \mathbf{0 . 8} \dagger$ & $\mathbf{5 . 9} \pm \mathbf{1 . 0}$ & $\mathbf{1 0 . 3} \pm \mathbf{1 . 2}$ & $\mathbf{5 3} \pm \mathbf{6}$ \\
Ase Bolong Kamandi & $\mathbf{7 1 . 4} \pm \mathbf{2 . 2}$ & $\mathbf{1 0 . 0} \pm \mathbf{0 . 7}$ & $\mathbf{1 8 . 6} \pm \mathbf{2 . 5}$ & $\mathbf{1 7 1} \pm \mathbf{9}$ \\
Ketan Lumbu & $\mathbf{6 9 . 0} \pm \mathbf{5 . 5}$ & $\mathbf{1 7 . 3} \pm \mathbf{3 . 5}$ & $\mathbf{1 3 . 7} \pm \mathbf{2 . 3}$ & $\mathbf{1 4 0} \pm \mathbf{9}$ \\
Kemandi Pance & $\mathbf{6 7 . 8} \pm \mathbf{2 . 2}$ & $\mathbf{1 9 . 6} \pm \mathbf{1 . 6}$ & $\mathbf{1 2 . 5} \pm \mathbf{0 . 8}$ & $\mathbf{1 4 5} \pm \mathbf{8}$ \\
Jimbrug & $\mathbf{6 3 . 7} \pm \mathbf{5 . 8}$ & $\mathbf{1 7 . 4} \pm \mathbf{2 . 7}$ & $\mathbf{1 8 . 9} \pm \mathbf{3 . 2}$ & $\mathbf{1 3 1} \pm \mathbf{1 0}$ \\
Gundil Kuning & $\mathbf{6 5 . 2} \pm \mathbf{3 . 8}$ & $\mathbf{1 3 . 0} \pm \mathbf{1 . 8}$ & $\mathbf{2 1 . 8} \pm \mathbf{3 . 6}$ & $\mathbf{1 4 2} \pm \mathbf{9}$ \\
Pare Bogor & $\mathbf{6 1 . 4} \pm \mathbf{3 . 3}$ & $\mathbf{2 0 . 0} \pm \mathbf{1 . 2}$ & $\mathbf{1 8 . 6} \pm \mathbf{2 . 4}$ & $\mathbf{1 2 8} \pm \mathbf{1 0}$ \\
Loas Gedjeh & $\mathbf{5 4 . 7} \pm \mathbf{5 . 7}$ & $\mathbf{2 2 . 1} \pm \mathbf{3 . 3}$ & $\mathbf{2 3 . 2} \pm \mathbf{3 . 6}$ & $\mathbf{1 3 2} \pm \mathbf{1 3}$ \\
Sopongono & $\mathbf{4 5 . 6} \pm \mathbf{3 . 7}$ & $\mathbf{2 4 . 7} \pm \mathbf{1 . 7}$ & $\mathbf{2 9 . 7} \pm \mathbf{4 . 7}$ & $\mathbf{1 5 8} \pm \mathbf{1 1}$ \\
Sarimahi & $\mathbf{3 7 . 3} \pm \mathbf{2 . 6}$ & $\mathbf{2 9 . 9} \pm \mathbf{2 . 1}$ & $\mathbf{3 2 . 8} \pm \mathbf{1 . 4}$ & $\mathbf{1 0 9} \pm \mathbf{3}$ \\
Ribon & $\mathbf{3 3 . 4} \pm \mathbf{4 . 0}$ & $\mathbf{3 3 . 4} \pm \mathbf{3 . 5}$ & $\mathbf{3 3 . 2} \pm \mathbf{5 . 9}$ & $\mathbf{1 5 3} \pm \mathbf{1 2}$ \\
Djawa Pelet & $\mathbf{2 8 . 8} \pm \mathbf{7 . 9}$ & $\mathbf{4 4 . 3} \pm \mathbf{6 . 2}$ & $\mathbf{2 7 . 0} \pm \mathbf{3 . 0}$ & $\mathbf{1 0 7} \pm \mathbf{7}$ \\
Sengkeu & $\mathbf{1 8 . 9} \pm \mathbf{2 . 2}$ & $\mathbf{3 7 . 9} \pm \mathbf{0 . 8}$ & $\mathbf{4 3 . 2} \pm \mathbf{1 . 8}$ & $\mathbf{1 3 3} \pm \mathbf{2 0}$ \\
\hline
\end{tabular}

$\dagger$ Mean \pm standard error of the mean. 
Table 5. Grain yield and yield components of top 5 new plant type lines and check cultivar IR72 grown in non-replicated observational trials at IRRI in the dry season and wet season of 1998. Forty-three and 51 new plant type lines were grown in the dry and wet season, respectively.

\begin{tabular}{|c|c|c|c|c|c|c|}
\hline Cultivar/line & Grain yield & $\begin{array}{c}\text { Panicles } \\
\mathbf{m}^{-2}\end{array}$ & $\begin{array}{l}\text { Spikelets } \\
\text { panicle }^{-1}\end{array}$ & $\begin{array}{l}\text { Spikelets m }^{-2} \\
\quad\left(\times \mathbf{1 0}^{3}\right)\end{array}$ & $\begin{array}{c}\text { Filled } \\
\text { spikelets }\end{array}$ & $\begin{array}{c}\text { 1000-grain } \\
\text { weight }\end{array}$ \\
\hline & $\operatorname{Mg~ha}^{-1}$ & & & & $\%$ & g \\
\hline \multicolumn{7}{|c|}{1998 dry season } \\
\hline IR70554-48-1-2 & $8.84 \pm 0.03 \dagger$ & $229 \pm 10$ & $161 \pm 7$ & $36.9 \pm 2.3$ & $71.6 \pm 0.7$ & $29.2 \pm 0.1$ \\
\hline IF65564-44-2-2 & $8.59 \pm 0.11$ & $216 \pm 11$ & $186 \pm 6$ & $40.1 \pm 0.9$ & $72.7 \pm 0.6$ & $25.1 \pm 0.1$ \\
\hline IR69093-41-2-3-2 & $8.45 \pm 0.03$ & $222 \pm 3$ & $186 \pm 6$ & $41.2 \pm 0.7$ & $77.8 \pm 1.6$ & $23.3 \pm 0.0$ \\
\hline IR68552-100-1-2-2 & $8.38 \pm 0.10$ & $234 \pm 2$ & $166 \pm 1$ & $38.9 \pm 0.7$ & $84.2 \pm 1.9$ & $24.9 \pm 0.1$ \\
\hline IR69853-70-3-1-1 & $8.27 \pm 0.20$ & $219 \pm 11$ & $195 \pm 1$ & $42.7 \pm 2.3$ & $65.7 \pm 0.9$ & $24.8 \pm 0.1$ \\
\hline IR72 & $8.07 \pm 0.36$ & $532 \pm 19$ & $90 \pm 1$ & $47.8 \pm 1.2$ & $80.9 \pm 0.7$ & $21.4 \pm 0.1$ \\
\hline \multicolumn{7}{|c|}{1998 wet season } \\
\hline IR65600-42-5-2 & $7.67 \pm \mathbf{0 . 1 0}$ & $327 \pm 6$ & $96 \pm 3$ & $31.4 \pm 1.0$ & $74.4 \pm 1.8$ & $22.7 \pm 0.0$ \\
\hline IR65564-44-2-3 & $6.90 \pm 0.22$ & $340 \pm 10$ & $110 \pm 3$ & $37.5 \pm 1.4$ & $58.5 \pm 3.1$ & $25.6 \pm 0.1$ \\
\hline IR66160-121-4-1-1 & $6.40 \pm 0.33$ & $383 \pm 15$ & $86 \pm 7$ & $32.5 \pm 1.6$ & $78.3 \pm 1.6$ & $22.2 \pm 0.1$ \\
\hline IR66158-38-3-2-1 & $6.39 \pm 0.08$ & $273 \pm 10$ & $139 \pm 7$ & $37.9 \pm 1.6$ & $52.0 \pm 2.3$ & $29.2 \pm 0.2$ \\
\hline IR66160-121-4-4-2 & $6.24 \pm 0.45$ & $328 \pm 14$ & $91 \pm 4$ & $29.6 \pm 1.2$ & $80.6 \pm 2.5$ & $24.5 \pm 0.2$ \\
\hline IR72 & $5.01 \pm 0.10$ & $469 \pm 17$ & $72 \pm 1$ & $33.7 \pm 1.7$ & $65.0 \pm 0.5$ & $20.1 \pm 0.1$ \\
\hline
\end{tabular}

$\dagger$ Mean \pm standard error of the mean; SE based on four samples per plot.

original ideotype design. Multiple site-year comparisons of NPT lines with highest yielding indica cultivars have shown that the original NPT design did not have sufficient tillering capacity. An increase in tillering capacity was needed to increase biomass production and to improve compensation when tillers are lost to insect damage or other causes during the vegetative stage. A slightly smaller panicle size without change in panicle length also appeared to be advantageous to reduce the compact arrangement of spikelets. Plant height is being increased by $10 \%$ with the hope that a taller stature allows greater biomass production without a decrease in lodging resistance. Other refinements in NPT traits are also used as selection criteria including low panicle height within a canopy (Setter et al., 1995) and high biomass at flowering. Some advanced NPT $\times$ indica lines $\left(\mathrm{F}_{5}\right.$ generation) with the above refinements have now been selected and were planted in a replicated observation trial for the first time in the 1998 WS. Indica germplasm can also help improve other NPT attributes such as grain quality and disease and insect resistance.

\section{Increasing Yield Potential with Hybrid Rice}

Hybrid rices have been grown in China since 1976. More than $50 \%$ of China's rice area is now planted to rice hybrids (Yuan et al., 1994), which have a mean yield advantage of about $15 \%$ over the best inbred cultivars (Yuan, 1994). In the late 1970s, these Chinese rice hybrids were evaluated in tropical lowland environments of Southeast Asia. They were poorly adapted and susceptible to diseases and insects (Virmani et al., 1982). In 1978, IRRI began to develop hybrids for the tropical lowlands (Khush, 1995). In the past $5 \mathrm{yr}$, some hybrid rices developed at IRRI have shown a yield advantage of about $15 \%$ compared to the best inbred cultivars when grown in farmers' fields. Recently, commercialization of hybrid rice has been initiated in India, Vietnam, and the Philippines (Virmani, 1996). About 50000 and 80000 ha were planted with hybrids in 1996 in India and Vietnam, respectively. By the year 2000, India and
Vietnam are planning to plant about 2 million and 500000 ha, respectively, with hybrid rices.

Although hybrid rices clearly produce higher yields under on-farm conditions than indica inbred cultivars, a key issue is whether hybrid rice increases rice yield potential in tropical environments. Several rice hybrids and indica inbred cultivars and lines were grown in four irrigated field experiments at IRRI and PhilRice research farms in the 1996 DS and 1997 DS. The crop management practices used in these studies were selected to minimize all possible stresses to achieve maximum possible yield levels. The mean maximum yield across the four experiments was $9.9 \pm 0.3 \mathrm{Mg} \mathrm{ha}^{-1}$ (mean $\pm \mathrm{SD}$ ) for inbreds and $10.8 \pm 0.4 \mathrm{Mg} \mathrm{ha}^{-1}$ for the hybrids (Fig. 4). These results suggest an increase in yield potential of indica hybrids of about $9 \%$ compared with the best indica inbred cultivars under tropical conditions. The higher yield potential of indica/indica hybrids compared with indica inbred cultivars was attributed to the greater biomass production rather than harvest index. Total dry matter at harvest of the hybrids at IRRI and PhilRice was 10 to $17 \%$ higher than that of inbred cultivar IR72 (data not shown).

In the rice literature, the yield advantage of hybrid rice has been attributed to greater dry matter production, which results from higher leaf area index (LAI) and a greater crop growth rate, and an increased harvest index, which results from greater spikelet number and sometimes an increase in single grain weight (Ponnuthurai et al., 1984; Akita et al., 1986; Agata, 1990; Song et al., 1990a; Patnaik et al., 1991; Peng et al., 1996). The reasons for the greater biomass and yield potential of hybrid rice are (i) an increased growth rate during early vegetative stages as a result of rapid expansion of leaf area and greater tiller number (Kabaki, 1993; Yamauchi, 1994), (ii) more efficient sink formation relative to the rate of dry matter accumulation that results in both greater biomass and larger panicles at flowering stage (Cao et al., 1980; Kabaki, 1993), and (iii) a relative high grain filling percentage despite the large number of spikelets (Yan, 1988; Song et al., 1990a). The latter 


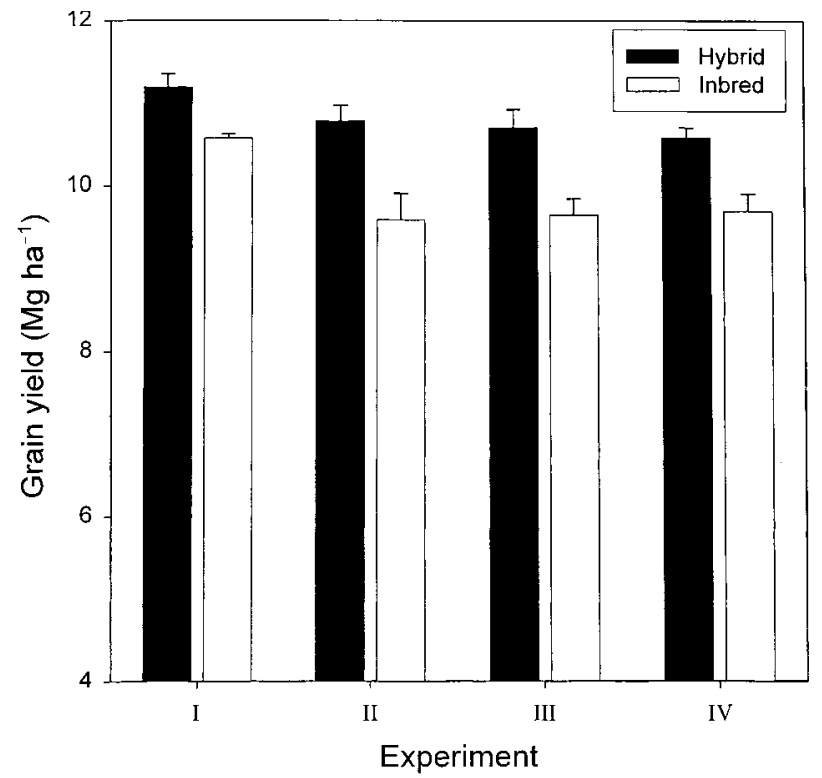

Fig. 4. Comparisons between the maximum yields of a hybrid and an inbred in four field experiments. Exp I was conducted at PhilRice farm in the dry season of 1996 with IR68284H (hybrid) and IR72 (inbred). Exp II was conducted at PhilRice farm in the dry season of 1997 with IR68284H and IR65469-161-2-2-3-2-2 (inbred). Exp III was conduced at IRRI farm in the dry season of 1997 with IR68284H and IR65469-161-2-2-3-2-2. Exp IV was conducted at PhilRice farm in the dry season of 1997 with IR68284H and IR59682-132-1-1-2 (inbred). Vertical, capped lines represent standard error of mean of four replications.

hybrid trait was associated with greater amounts of stored carbohydrate reserves translocated from the culm and sheath to the spikelets and an increased LAI during the ripening period than for inbred cultivars (Yan, 1981; Song et al., 1990a). Song et al. (1990b) also observed that non-structural carbohydrate content in the culm and sheath was greater in hybrid than inbred rices.

Although the growth and development processes associated with the yield potential advantage of hybrid rice have been identified, the physiological basis for this heterosis remains unknown. Single-leaf photosynthesis was measured in several studies to determine whether differences in net assimilation rates contributed to the increased growth rate of hybrid rice, but the results have not been consistent (Akita, 1988). At IRRI, single-leaf photosynthetic rates of hybrid IR64616H and the inbred cultivar IR72 were measured in the 1993 DS. The hybrid did not have a higher single-leaf photosynthetic rate than the inbred at anytime during the growing season (Table 6). In fact, the hybrid had a lower single-leaf photosynthetic rate during vegetative and grain filling phases because of lower leaf $\mathrm{N}$ concentration than in the inbred cultivar. Sinclair and Horie (1989) compared leaf $\mathrm{N}$ concentration, single-leaf photosynthetic rate, LAI, and crop biomass production among rice, soybean [Glycine max (L.) Merr.], and maize. They argued that crop species with a lower $\mathrm{N}$ concentration but equivalent total leaf $\mathrm{N}$ will have a greater LAI and biomass accumulation. The greater LAI and lower leaf $\mathrm{N}$ concentration of the hybrid is consistent with this hypothesis and might
Table 6. Single leaf photosynthetic rate and leaf $\mathbf{N}$ concentration per unit leaf area of a hybrid (IR64616H) and an indica inbred cultivar (IR72) grown in the dry season of 1993, IRRI farm. Measurements were taken on topmost fully expanded leaves at different days after transplanting (DAT). Each value is a mean of 48 measurements.

\begin{tabular}{|c|c|c|c|c|}
\hline \multirow[b]{2}{*}{ DAT } & \multicolumn{2}{|c|}{ Photosynthetic rate } & \multicolumn{2}{|c|}{ Leaf $N$ concentration } \\
\hline & IR64616H & IR72 & IR64616H & IR72 \\
\hline & \multicolumn{2}{|c|}{$-\mu \mathrm{mol} \mathrm{CO} \mathbf{C O}_{2} \mathbf{m}^{-2} \mathbf{s}^{-1}-$} & \multicolumn{2}{|c|}{$\longrightarrow \mathrm{g} \mathrm{N} \mathrm{m}^{-2}$} \\
\hline 38 & $24.9 \mathrm{~b} \dagger$ & 29.0a & $1.30 \mathrm{~b}$ & 1.48a \\
\hline $50 \%$ & $9.4 a$ & 9.3a & $1.34 \mathrm{~b}$ & $1.58 \mathbf{a}$ \\
\hline 63 & 23.2b & 24.9a & $1.31 \mathrm{~b}$ & $1.53 a$ \\
\hline 88 & $20.8 b$ & 24.6a & $1.03 b$ & $1.35 \mathrm{a}$ \\
\hline
\end{tabular}

$\dagger$ For each parameter, means followed by different letter (within a row) are significantly different at the 0.05 probability level according to LSD. \$ Photosynthetic rate was measured at PAR $<400 \mu \mathrm{mol} \mathrm{m}^{-2} \mathrm{~s}^{-1}$ on 50 DAT and at saturated light (PAR around $2000 \mu \mathrm{mol} \mathrm{m} \mathrm{m}^{-2} \mathrm{~s}^{-1}$ ) on the other dates.

therefore contribute to the observed heterosis in biomass production and grain yield.

Almost all rice hybrids grown in China and those developed at IRRI have been crosses between indica cultivars (Khush, 1995). The magnitude of heterosis depends on the genetic diversity between the two parents. The greater the genetic difference between the parents, the higher the heterosis. During the past $30 \mathrm{yr}$, genetic diversity among improved indica rices has narrowed because of the massive international exchange of germplasm (Khush and Aquino, 1994). However, indica and japonica germplasms have remained distinct as there has been little gene flow between these two groups. As expected, hybrids made from crosses between indica and japonica had greater heterosis for yield than did indica/indica hybrids (Yuan et al., 1989). The major limitation of indica/temperate japonica hybrids is the poor grain filling (Zhu et al., 1997), however. The NPT development program was based solely on use of tropical japonica germplasm so that improved lines could also be used for producing indica/tropical japonica hybrids. Hybrids between indica cultivars and the NPT tropical japonicas are presently under evaluation at IRRI. Preliminary results show that the level of heterosis in the indica/tropical japonica hybrid is higher than that of indica/indica hybrids (Virmani, unpublished), and the grain filling of indica/tropical japonica hybrid was better than the NPT lines. Utilization of NPT tropical japonica may provide an avenue to improve the poor grain filling of intersubspecific hybrid rice.

\section{Conclusions}

Empirical breeding for population improvement has resulted in the maintenance of rice yield potential in the tropics of about $10 \mathrm{Mg} \mathrm{ha}^{-1}$. The most recently developed cultivars such as IR72 and PSBRc52 have a yield potential in this range (Fig. 5). The maximum yield of IR8 has been reduced by about $2 \mathrm{Mg} \mathrm{ha}^{-1}$ during the past $30 \mathrm{yr}$, which indicates the importance of maintenance breeding. Utilization of heterosis and modification of plant type are the primary strategies now being used to increase the yield potential of irrigated lowland rice in the tropics. Intervarietal hybrid rice between 


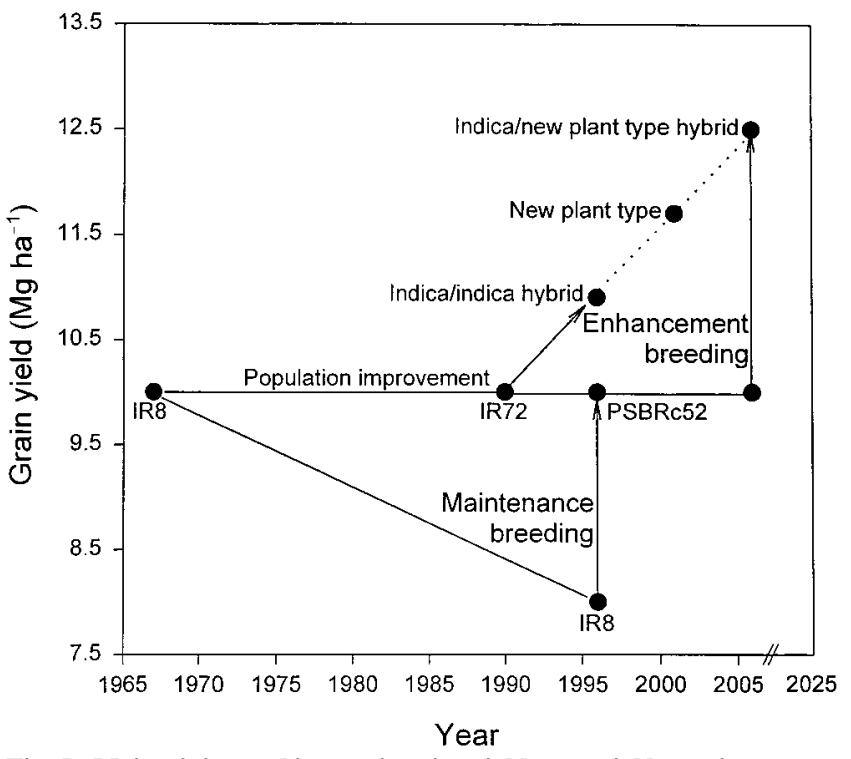

Fig. 5. Maintaining and increasing rice yield potential by maintenance breeding and enhancement breeding. Empirical breeding approach is used to improve population and to maintain rice yield potential. Utilization of heterosis and modification of plant type are the major components of enhancement breeding to increase rice yield potential.

indicas can increase yield potential by about $9 \%$. New plant type breeding has not yet improved yield potential. Poor grain filling and low biomass production limit the full expression of yield potential of the NPT. Selecting parents with good grain filling traits, introduction of indica genes, and a refinement of original NPT design are expected to improve the performance of the NPT lines. Further enhancement in yield potential may be possible from use of intersubspecific heterosis between indica and NPT lines.

\section{ACKNOWLEDGMENTS}

We thank R.C. Laza, A.L. Sanico, and R.M. Visperas for their technical assistance in managing the field experiments and data collection.

\section{REFERENCES}

Agata, W. 1990. Mechanism of high yielding achievement in Chinese $\mathrm{F}_{1}$ rice compared with cultivated rice varieties. Jpn. J. Crop Sci. (In Japanese) 59:270-273.

Akita, A. 1988. Physiological bases of heterosis in rice. p. 67-77. In Hybrid Rice. International Rice Research Institute, Los Baños, Philippines.

Akita, A., L. Blanco, and S.S. Virmani. 1986. Physiological analysis of heterosis in rice plant. Jpn. J. Crop Sci. 65:14-15.

Cao, X., Q. Zhu, J. Yang, and Y. Gu. 1980. Studies on the percentage of ripened grains of hybrid rice. Sci. Agric. Sin. (In Chinese) 2:44-50.

Cassman, K.G. 1999. Ecological intensification of cereal production systems: Yield potential, soil quality, and precision agriculture. Proc. National Acad. Sci. (USA). 96:5952-5959.

Cassman, K.G., S.K. De Datta, D.C. Olk, J.M. Alcantara, M.I. Samson, J.P. Descalsota, and M.A. Dizon. 1995. Yield decline and the nitrogen economy of long-term experiment on continuous, irrigated rice systems in the tropics. p. 19-81-222. In R. Lal and B.A. Stewart (ed.) Soil management: Experimental basis for sustainability and environmental quality. Lewis/CRC Publishers, Boca Raton, FL.

Chandler, R.F.Jr. 1969. Plant morphology and stand geometry in relation to nitrogen. p. 265-285. In J.D. Eastin, F.A. Haskins, C.Y.
Sullivan, and C.H.M. van Bavel (ed.) Physiological aspects of crop yield. ASA, Madison, WI.

De Datta, S.K., A.C. Tauro, and S.N. Balaoing. 1968. Effect of plant type and nitrogen level on growth characteristics and grain yield of indica rice in the tropics. Agron. J. 60:643-647.

Dingkuhn, M., F.W.T. Penning de Vries, S.K. De Datta, and H.H. van Laar. 1991. Concepts for a new plant type for direct seeded flooded tropical rice. p. 17-38. In Direct seeded flooded rice in the tropics. International Rice Research Institute, Los Baños, Philippines.

Donald, C.M. 1968. The breeding of crop ideotypes. Euphytica 17:385-403.

Flinn, J.C., S.K. De Datta, and E. Labadan. 1982. An analysis of longterm rice yields in a wetland soil. Field Crops Res. 5:201-216.

IRRI. 1989. IRRI towards 2000 and beyond. p. 36-37. International Rice Research Institute, Los Baños, Philippines.

Janoria, M.P. 1989. A basic plant ideotype for rice. Intl. Rice Res. Newsl. 14:12-13.

Kabaki, N. 1993. Growth and yield of japonica-indica hybrid rice. JARQ 27:88-94.

Khush, G.S. 1990. Varietal needs for different environments and breeding strategies. p. 68-75. In K. Muralidharan and E.A. Siddiq (ed.) New Frontiers in rice research. Directorate of Rice Research, Hyderabad, India.

Khush, G.S. 1995. Breaking the yield frontier of rice. GeoJournal 35:329-332.

Khush, G.S., and R.C. Aquino. 1994. Breeding tropical japonicas for hybrid rice production. p. 33-36. In S.S. Virmani (ed.) Hybrid rice technology: New Developments and future prospects. International Rice Research Institute, Los Baños, Philippines.

Khush, G.S., and S. Peng. 1996. Breaking the yield frontier of rice. p. 36-51. In M.P. Reynolds et al. (ed.) Increasing yield potential in wheat: Breaking the barriers, Ciudad Obregon, Sonora. 26-28 March, 1996. International Maize and Wheat Improvement Center, Mexico, D.F., Mexico.

Kropff, M.J., Cassman, H.H. van Laar, and S. Peng. 1993. Nitrogen and yield potential of irrigated rice. Plant Soil 155/156:391-394.

Ku, S.B., S. Agarie, M. Nomura, H. Fukayama, H. Tsuchida, K. Ono, S. Hirose, S. Toki, M. Miyao, and M. Matsuoka. 1999. High-level expression of maize phosphoenolpyruvate carboxylase in transgenic rice plants. Nature Biotechnology 17:76-80.

Ladha, J.K., G.J.D. Kirk, J. Bennett, S. Peng, C.K. Reddy, P.M. Reddy, and U. Singh. 1998. Opportunities for increased nitrogen-use efficiency from improved lowland rice germplasm. Field Crops Res. 56:41-71.

Matthews R.B., T. Horie., M.J. Kropff, D. Bachelet, H.G. Centeno, J.C. Shin, S. Mohandass, S. Singh, D. Zhu, and M.H. Lee. 1995. A regional evaluation of the effect of future climate change on rice production in Asia. p. 95-139. In R.B. Matthews et al. (ed.) Modeling the impact of climate change on rice production in Asia. CAB International, Wallingford, UK.

Patnaik, R.N., K. Pande, S.N. Ratho, and P.J. Jachuck. 1991. Consistent performance of rice hybrids. Crop Res. 4:272-279.

Peng, S., F.V. Garcia, R.C. Laza, A.L. Sanico, R.M. Visperas, and K.G. Cassman. 1996. Increased N-use efficiency using a chlorophyll meter on high yielding irrigated rice. Field Crops Res. 47:243-252.

Peng, S., G.S. Khush, and K.G. Cassman. 1994. Evaluation of a new plant ideotype for increased yield potential. p. 5-20, In K.G. Cassman (ed.) Breaking the yield barrier: Proc. of a workshop on rice yield potential in favorable environments, Los Baños, Philippines. 29 Nov.-4 Dec. 1993. International Rice Research Institute, Los Baños, Philippines.

Peng, S., R.C. Laza, R.M. Visperas, A.L. Sanico, K.G. Cassman, and G.S. Khush. 2000. Grain yield of rice cultivars and lines developed in the Philippines since 1966. Crop Sci. 40. (in press).

Peng, S., J. Yang, F.V. Garcia, R.C. Laza, R.M. Visperas, A.L. Sanico, A.Q. Chavez, and S.S. Virmani. 1998. Physiology-based crop management for yield maximization of hybrid rice. p. 157-176. In S.S Virmani, E.A. Siddiq, and K. Muralidharan (ed.) Advances in hybrid rice technology. Proc. of the Third International Symposium on Hybrid Rice, Hyderabad, India, 14-16 Nov. 1996. International Rice Research Institute, Los Baños, Philippines.

Ponnuthurai, S., S.S. Virmani, and B.S. Vergara. 1984. Comparative 
studies on the growth and grain yield of some $\mathrm{F}_{1}$ rice (Oryza sativa L.) hybrids. Philipp. J. Crop Sci. 9:183-193.

Rasmusson, D.C. 1991. A plant breeder's experience with ideotype breeding. Field Crops Res. 26:191-200.

Setter, T.L., E.A. Conocono, J.A. Egdane, and M.J. Kropff. 1995. Possibility of increasing yield potential of rice by reducing panicle height in the canopy. I. Effects of panicles on light interception and canopy photosynthesis. Aust. J. Plant Physiol. 22:441-451.

Sinclair, T.R., and T. Horie. 1989. Leaf nitrogen, photosynthesis, and crop radiation use efficiency: A review. Crop Sci. 29:90-98.

Song, X., W. Agata, and Y. Kawamitsu. 1990a. Studies on dry matter and grain production of $F_{1}$ hybrid rice in China. II. Characteristics of grain production. Jpn. J. Crop Sci. 59:29-33.

Song, X., W. Agata, and Y. Kawamitsu, Y. 1990b. Studies on dry matter and grain production of $F_{1}$ hybrid rice in China. III. Grain production characters from the view-point of time changes in nonstructural carbohydrate and nitrogen contents during the yield production. Jpn. J. Crop Sci. 5:107-112.

Vergara, B.S. 1988. Raising the yield potential of rice. Philipp. Tech. J. 13:3-9.

Virmani, S.S. 1996. Hybrid rice. Adv. Agron. 57:377-462.

Virmani, S.S., R.C. Aquino, and G.S. Khush. 1982. Heterosis breeding in rice, Oryza sativa L. Theor. Appl. Genet. 63:373-380.

Xiao, J., J. Li, S. Grandillo, S.N. Ahn, L. Yuan, S.D. Tanksley, and S.R. McCouch. 1998. Identification of trait-improving quantitative trait loci alleles from a wild rice relative, Oryza rufipogon. Genetics 150:899-909.

Yamagishi, T., S. Peng, K.G. Cassman, and R. Ishii. 1996. Studies on grain filling characteristics in "New Plant Type" rice lines developed in IRRI. Japanese J. Crop Sci. 65 (Extra issue No.2):169-170.

Yamauchi, M. 1994. Physiological bases of higher yield potential in $F_{1}$ hybrids. p. 71-80. In S.S. Virmani (ed.) Hybrid rice technology: New developments and future prospects. International Rice Research Institute, Los Baños, Philippines.
Yan, Z.D. 1981. Studies on the production and distribution of dry matter in high yielding populations of hybrid rice. Acta Agron. Sin. (In Chinese) 7:11-18.

Yan, Z.D. 1988. Agronomic management of rice hybrids compared with conventional varieties. p. 217-223. In Hybrid rice. International Rice Research Institute, Los Baños, Philippines.

Yoshida, S. 1981. Fundamentals of rice crop science. International Rice Research Institute, Los Baños, Philippines.

Yoshida, S., and F.T. Parao. 1972. Performance of improved rice varieties in the tropics with special reference to tillering capacity. Exp. Agric. 8:203-212.

Yuan, L.P. 1994. Increasing yield potential in rice by exploitation of heterosis. p. 1-6. In S.S. Virmani (ed.) Hybrid rice technology: New developments and future prospects. International Rice Research Institute, Los Baños, Philippines.

Yuan, L.P., S.S. Virmani, and C.X. Mao. 1989. Hybrid rice - achievements and future outlook. p. 219-223. In Progress in irrigated rice research. International Rice Research Institute, Los Baños, Philippines.

Yuan, L.P., Z.Y. Yang, and J.B. Yang. 1994. Hybrid rice in China. p. 143-147. In S.S. Virmani (ed.) Hybrid rice technology: New developments and future prospects. International Rice Research Institute, Los Baños, Philippines.

Zhang, Y., S.E. Chantler, S. Gupta, Y. Zhao, D. Leisy, L.C. Hannah, C. Meyer, J. Weston, M.-X. Wu, J. Preiss, and T.W. Okita. 1996. Molecular approaches to enhance rice productivity through manipulations of starch metabolism during seed development. p. 809-813. In G.S. Khush (ed.) Rice genetics III. Proc. of the Third International Rice Genetics Symposium, Manila, Philippines. 16-20 October 1995. International Rice Research Institute, Los Baños, Philippines.

Zhu, Q., Z. Zhang, J. Yang, X. Cao, Y. Lang, and Z. Wang. 1997. Source-sink characteristics related to the yield in intersubspecific hybrid rice. Sci. Agric. Sin. (In Chinese) 30:52-59. 